\title{
LUDOTERAPIA EM PSICANÁLISE: O REAL DA CRIANÇA E DAS BRINCADEIRAS
}

\author{
GOMES, T.B.S., RIBEIRO, M.A., BRAGANÇA, A.G., PIZETA, H.S., \\ GREGIO, L.B., BUCHVITZ, P.A. \\ Departamento de Psicologia - Centro de Pesquisa Institutos Superiores de Ensino do CENSA - \\ ISECENSA. Rua Salvador Correa, 139, Centro, Campos dos Goytacazes, RJ, Brasil.
}

Tradicionalmente acredita-se que há um vínculo direto e imediato entre a criança, o brinquedo e o brincar. Parte-se da ideia de que a criança, na história da humanidade, sempre teve brinquedos e brincou. Não havendo nada mais natural que a associação criança, brincadeira e jogos infantis. As crianças não chegam isentas ao consultório. Elas trazem no pensamento, nas emoções ou na forma de brincar a maneira como foram olhadas e percebidas pelos outros. Ao brincar, a criança não se situa apenas no momento presente; mas, também seu passado e futuro. Este trabalho tem como objetivo analisar teoria e a técnica nos atendimentos de crianças a partir da psicanálise infantil. Utilizaremos uma revisão da literatura. $\mathrm{O}$ brincar, como atividade terapêutica, possibilita que a criança supere a situação traumática. É simbolizando, falando e representando os conteúdos que a perturbaram que criança nomeia e conhece melhor as situações, ideias, pessoas e coisas. O brinquedo, da mesma forma que o brincar, não é um objeto neutro, pois condensa a história da criança com outros objetos. A criança não repete situações passadas apenas porque elas têm determinados sentidos e significações. Ela repete porque elas passam a se constituir em formas de gozar. A criança não repete certas ações desagradáveis apenas para chamar a atenção do psicólogo. Ela faz porque aquilo tem um determinado sentido, porque se encontra preza em cadeias de gozo das quais não consegue sair. Quando a criança se aproxima de um brinquedo, para brincar, já está aparelhada com formas estruturadas de pensar e de saber. Costuma-se dar como naturais os conteúdos referentes às ligações entre a criança, os brinquedos, as brincadeiras e os jogos infantis. Ao longo deste trabalho fomos revelando que estas ideias não se apresentam juntas. Elas se estruturam tanto a partir de concepções sociais quanto individuais. É preciso que nós saiamos destas concepções preestabelecidas para que realmente possamos identificar como a criança pensa, brinca e joga. Como ela concebe os brinquedos, jogos e brincadeiras. $\mathrm{O}$ apreender a criança através das etapas de desenvolvimento, se age de uma forma redutora, fazendo a criança se encaixar na linguagem que conhecemos. Há um novo no brincar, nos brinquedos e jogos infantis que precisa ser resgatado pelos psicanalistas e pesquisadores infantis. Um novo que sempre existiu. Um novo que pertence ao registro do real, mas que por nossas construções de linguagem, nós sempre tentamos apreender à nossa moda, perdendo muitas vezes, irremediavelmente a criança, o brincar e o brinquedo.

Palavras-chave: criança, brincar, psicanálise, brinquedo, novo.

\section{Referências}

MRECH, Leny Magalhães. Psicanálise e educação: novos operadores de leitura. São Paulo: Editora Pioneiro, 2007.

LACAN, Jacques. La familia. Buenos Aires, Homo Sapiens, 1977. 